\title{
The influence of untreated sugarcane bagasse ash on the microstructural and mechanical properties of mortars
}

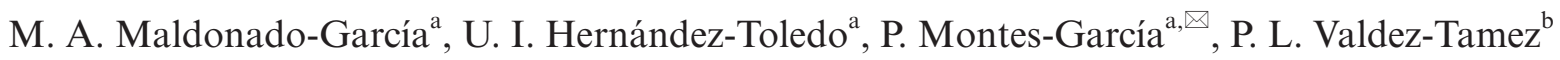 \\ a. Instituto Politécnico Nacional, CIIDIR-Oaxaca, (Oaxaca, México) \\ b. Universidad Autónoma de Nuevo León, FIC, (Nuevo León, México) \\ $\bowtie$ pmontesgarcia@gmail.com,pmontes@ipn.mx
}

\author{
Received 17 December 2016 \\ Accepted 24 May 2017 \\ Available on line 19 February 2018
}

\begin{abstract}
This study investigated the effects of the addition of untreated sugarcane bagasse ash (UtSCBA) on the microstructural and mechanical properties of mortars. The SCBA was sieved for only five minutes through a No. 200 ASTM mesh, and fully characterized by chemical composition analysis, laser ray diffraction, the physical absorption of gas, scanning electron microscopy (SEM) and X-ray diffraction (XRD) techniques. Mortar mixtures with 0, 10 and 20\% UtSCBA as cement replacement and a constant 0.63 water/cementitious material ratio were prepared. Fresh properties of the mortars were obtained. The microstructural characteristics of the mortars at 1, 7, 28, 90 and 600 days were evaluated by SEM and XRD. The compressive strengths of the mortars at the same ages were then obtained. The results show that the addition of 10 and $20 \%$ UtSCBA caused a slight decrease in workability of the mortars but improved their microstructure, increasing the long-term compressive strength.
\end{abstract}

Keywords: Pozzolan, waste treatment, mortar, hydration products, compressive strength

Citation/Citar como: Maldonado-García, M.A.; Hernández-Toledo, U.I.; Montes-García, P.; Valdez-Tamez, P.L. (2018) The influence of untreated sugarcane bagasse ash on the microstructural and mechanical properties of mortars. Mater. Construcc. 68 [329], e148. https://doi.org/10.3989/mc.2018.13716

RESUMEN: Influencia de la ceniza de bagazo de caña sin tratamiento en la microestructura y propiedades mecánicas de morteros. En esta investigación se evaluó el efecto de la adición de ceniza de bagazo de caña (CBC) en la microestructura de morteros. La CBC fue tamizada durante 5 minutos a través de la malla No. 200 ASTM y evaluada mediante pruebas de análisis químico, difracción láser, absorción física de gases, Microscopia Electrónica de Barrido (MEB) y Difracción de Rayos X (DRX). Se elaboraron mezclas de mortero con 0, 10 y $20 \%$ de CBC como sustituto parcial del cemento manteniendo una relación agua/materiales-cementantes de 0.63. Se realizaron pruebas en estado fresco y pruebas de caracterización microestructural a través de MEB y DRX y de resistencia a la compresión a edades de 1, 7, 28, 90 y 600 días. Los resultados muestran que la adición de 10 y $20 \%$ de CBC decrementa la trabajabilidad de los morteros, sin embargo, mejora su microestructura e incrementa su resistencia a la compresión a edades tardías.

Palabras clave: Puzolana, Tratamiento de residuos, Mortero, Productos de hidratación, Resistencia a la compresión

ORCID ID: M. A. Maldonado-García (http://orcid.org/0000-0002-9522-6779); U. I. Hernández-Toledo (http://orcid. org/0000-0001-9392-0487); P. Montes-García (http://orcid.org/0000-0003-3799-8372); P. L. Valdez-Tamez (http://orcid. org/0000-0002-1298-2051)

Copyright: (C) 2018 CSIC. This is an open-access article distributed under the terms of the Creative Commons Attribution 4.0 International (CC BY 4.0) License. 


\section{INTRODUCTION}

Portland cement is used in concrete and is considered one of the most fundamental and widely produced materials for civic infrastructure projects around the world (1-4). Concrete is second to water in the total volume consumed per person, approximately three tons annually (3-4). However, cement production is a highly energy-intensive process. The manufacture of each ton of Portland cement emits approximately $0.8-1.0$ ton of anthropogenic $\mathrm{CO}^{2}$ (depending on the ratio of clinker to cement) into the atmosphere $(1-2,5)$. This represents $3-5 \%$ of current global emissions (1-3), which contribute to consequential environmental damage.

As a remedial measure, pozzolanic materials are now used as a partial substitute for Portland cement in concrete. Numerous studies show that SCBA can be used as a pozzolanic material when it is burned at temperatures between 600 and $1000^{\circ} \mathrm{C}$ and subjected to post-treatment such as recalcination or grinding. Results indicate that such post-treatments change some of the physical characteristics and chemical composition of the SCBA, as well as improve the pozzolanic potential (6-12). A post-treatment leads to the formation of silica, alumina $(7-9,13)$, and especially amorphous silica (6-7). These compounds react with calcium hydroxide $(\mathrm{CH})$, released during the hydration of cement, to form additional cementitious compounds such as calcium silicate hydrate $(\mathrm{C}-\mathrm{S}-\mathrm{H})$, thus improving the microstructural properties of concrete and mortar mixtures. This could lead to an improvement of some durability properties without having negatives effects on physical and mechanical properties $(6-8,11,14-16)$.

As previously mentioned, most research has focused on the effect of post-treatments of the SCBA in order to improve its potential activity and mechanical properties when used as a pozzolan in mortar and concrete; nevertheless, such treatments demand high levels of energy and contribute, once again, to generating contaminants. SCBA is a byproduct widely available in Mexico. According to Mexico's Union Nacional de Cañeros (National Union of Sugarcane Producers) (17), approximately 54 million tons of sugarcane are produced annually, from which some 15 million tons of bagasse are obtained. Akram et al. (18) reported that each ton of sugarcane produces approximately $0.62 \%$ of residual ash. This suggests that in Mexico approximately 0.34 million tons of SCBA are produced every year, which are mainly deposited in open garbage dumps, causing significant disposal problems and pollution.

Taking these last observations into consideration, it was decided that in this study the SCBA would be used practically as received from the sugar mill (subjected only to sieving, a low energy posttreatment) as a partial replacement for Portland cement. Our proposal was to evaluate the mechanical properties and the microstructure of mortars made with relatively untreated bagasse ash.

\section{EXPERIMENTAL}

\subsection{Selection of a low-energy post-treatment method for the "as received" SCBA}

The SCBA was collected from a sugar mill located in the community of Tezonapa, Veracruz, México. This ash is generated as a combustion by-product of sugarcane bagasse at temperatures between 550 and $700^{\circ} \mathrm{C}$ and recovered by sprinkling water during the sugar production. The collected ash was homogenized and dried for 24 hours in an electric oven at $105^{\circ} \mathrm{C}$

In order to select the SCBA to be used in subsequent phases of this research, its pozzolanic potential was estimated at 7,14 and 28 days after the ash was subjected to two low-energy post-treatments. The first post-treatment consisted of sieving the SCBA for five minutes through No. $8(2.36 \mathrm{~mm})$, No. $100(150 \mu \mathrm{m})$ and No. $200(75 \mu \mathrm{m})$ ASTM sieves (SCBA8, SCBA100 and SCBA200). The fractions removed in the sieving process were 0,20 y $30 \%$ for the No. $8(2.36 \mathrm{~mm})$, No. $100(150 \mu \mathrm{m})$ and No. 200 $(75 \mu \mathrm{m})$ sieves, respectively.

The second post-treatment consisted of sieving through the same sieves for the same period of time followed by two hours of grinding (SCBA8g, SCBA100g and SCBA200g). Sieving was carried out to reduce the particle size and to remove organic material, and posterior grinding was done solely to increase the specific surface area of the SCBA (7, 9,12,19-21). Ordinary Portland Cement CPO 40 Lafarge ${ }^{\circledR}$, SCBA from each post-treatment (at 20\% cement replacement), standard silica sand and distilled water were used to prepare mortar cubes in order to obtain the strength activity indexes (SAI) (ASTM C 311) of the six post-treated SCBAs. A mortar mixture (FA20) containing 20\% Admix Tech ${ }^{\circledR}$ Class F Fly Ash (FA) was prepared as a reference; the FA meets the requirements described in the ASTM C 618 standard.

Originally, water/cement or cementitious materials and sand/cement ratios of 0.484 and 2.75 were used to prepare the mortars in accordance with the ASTM C 311. However, a water/cement ratio of 0.57 for the control mortar and a water/cementitious material ratio of 0.68 for mortars containing 20\% SCBA were necessary to keep the sand/cementitious material ratio of 2.75 (ASTM C 311) and to fulfill the mortars' flow of $110 \pm 5 \%$ (ASTM C 1437). A water/cementitious material ratio of 0.56 was used for the mortar containing $20 \%$ FA to keep the same sand/cement ratio and as well fulfill the mortars' flow requirements. No superplasticizer was used in these experiments. 


\subsection{Selection of the SCBA used for preparation of the mortars}

SAIs for sieved and ground SCBAs and for the FA estimated at 7, 14 and 28 days are presented in Figure 1. In accordance with the literature, the SAI value increases when the particle size of the SCBA decreases as a result of sieving or grinding; the SAI also increases with age as a consequence of the pozzolanic reaction $(7-9,12,21)$.

Most mixtures had 28-day compressive strength values higher than $75 \%$ of the control mixture specified by the ASTM C 618 (this percentage was considered as a reference point for the analysis since the ASTM C 618 accounts for the various materials from natural resources requiring calcination to induce satisfactory properties). The only value smaller than $75 \%$ was for the mortar containing the material that passed the No. 8 sieve (SCBA8).

Poor performance of grinding SCBA after passing through the No. 8 and 100 sieves is supported by the fact that the wider sieves allow the passage of larger carbon particles, while a posterior grinding is not effective in increasing the SAI, as carbon particles are ground together along with particles rich in silica and alumina.

The mixture with 20\% FA (FA20) yielded the highest SAIs at the studied ages (98, 95 and 104\% at 7,14 and 28 days respectively) followed by the mixture with the combination of sieved plus ground SCBA (SCBA200g) (90, 87 and 95 at 7, 14 and 28 days respectively), and then only sieved SCBA (SCBA200) (85, 91 and 92\% at 7, 14 and 28 days respectively). As may be observed, the difference between SCBA200g and SCBA200 was not significant.
Based on the above information, it was decided to use only SCBA sieved through sieve No. $200(75 \mu \mathrm{m})$ (SCBA200) for the remaining stages of the present research. The SAI at the three ages of the selected SCBA was more than $75 \%$; therefore, this material can be considered a natural pozzolan, in accordance with the ASTM C 618.

\subsection{Characterization of materials}

From analyzing the results of the previous section, SCBA200, the material in which the posttreatment consisted of sieving it only through the No. $200(75 \mu \mathrm{m})$ sieve for five minutes, was selected as the study subject for the following phase of this research. For brevity SCBA200 will be further designated only as UtSCBA (Untreated Sugarcane Bagasses Ash).

Blended Portland Cement 30R Holcim Apasco $\AA$ (CPC) (approximately 5\% ground granulated blast furnace slag), which is readily available in southwestern México, was chosen as the cementing material.

Chemical composition, particle size distribution (PSD), density (ASTM C 188) and specific surface area (SSA) of the CPC and UtSCBA were obtained. The PSDs were obtained by wet method (via isopropyl alcohol) using a laser analyzer Microtrac S3500®; shape particles and refractive indices of 1.70 and 1.54 for CPC and UtSCBA were considered respectively. The SSAs were obtained by physical adsorption of nitrogen using a Quantachrome Nova 2000e ${ }^{\circledR}$ analyzer; the BET method was used for the analysis. The morphology and mineralogical phases of the UtSCBA were analyzed by SEM and XRD, respectively. The morphology of the materials was observed using a scanning electron microscope

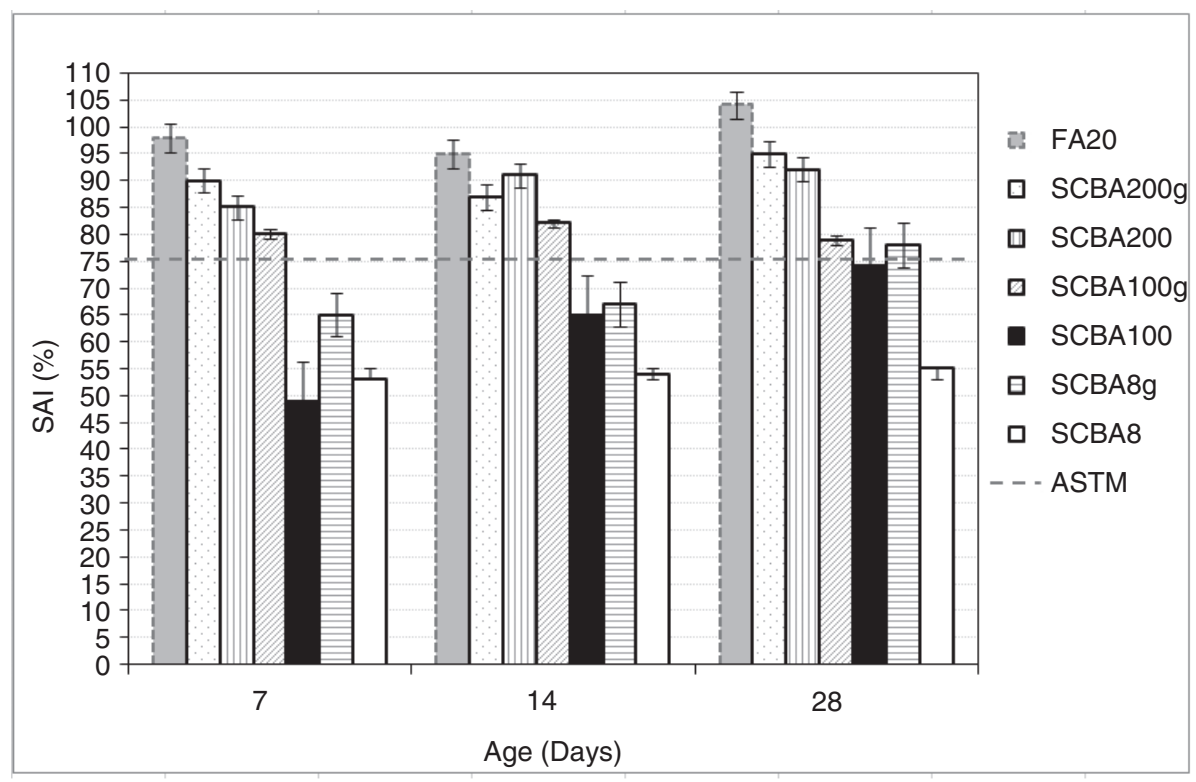

Figure 1. SAIs at 7, 14 and 28 days for samples with $20 \%$ sieved and ground SCBA. 
JEOL JSM-6490LV® equipped with an X-ray scattering analyzer (EDS) from Oxford Instruments 7573®. Mineralogical phases were identified using a diffractometer Bruker D8 Advance $\AA$, which uses radiation of $\mathrm{CuK}$ and a wavelength of $1.5418 \AA$ to a passage of $0.05^{\circ}$ and a time of incidence of 0.5 seconds per step, maintaining an interval $2 \theta$ from $10^{\circ}$ to $70^{\circ}$.

\subsection{Mixture proportioning and preparation of the mortars}

$\mathrm{UtSCBA}$, river sand (with a density of $2.7 \mathrm{~g} / \mathrm{cm}^{3}$ and a fineness modulus of 2.45 (ASTM C 33), distilled water and a high-range water reducer (HRWR), Plastol 4000® (ml per kg of cementitious materials), were used to prepare the mortars. All mortars had a 0.63 water/cementitious material, a 1:3 cementitious material to sand ratio, and were prepared replacing 0,10 and $20 \%$ of the weight of cement by UtSCBA (Control, UtSCBA10 and UtSCBA20 mixtures, respectively) (Table 1$)$.

Flow table (ASTM C1437), temperature (ASTM C1064/C1064M), volumetric weight (ASTM C138/ C138M) and air content (ASTM C231) tests of the mortars were carried out. Cylindrical specimens with a diameter of $75 \mathrm{~mm}$ and a height of $150 \mathrm{~mm}$ were prepared to study the microstructure and obtain the compressive strength. All specimens were cast in two layers and compacted using a vibrating table. Only the mixtures with an addition of UtSCBA required HRWR to maintain the workability. Specimens were cured in a $3 \%$ calcium hydroxide solution until the time of the test.

\subsection{Mortar test methods}

The morphology of gold-palladium-covered mortar samples at 1, 7, 28, 90 and 600 days were analyzed using a scanning electron microscope JEOL JSM-6490LV®. The mineralogical phases of mortar samples ground and sieved through a 150 $\mu \mathrm{m}$ mesh (ASTM) at 1, 7, 28, 90 and 600 days were identified by XRD using a diffractometer Bruker D8 Advance $\AA$ and were analyzed by the software EVA version 11.0.0.3 $\AA$. The compressive strengths (ASTM C 39/C39M) at 1, 7, 28, 56, 90, and 450 days were obtained by using a hydraulic press ELVEC E $659 \AA$. The compressive strength at 600 days was obtained from small mortar cubes ( 50 x 50 x $50 \mathrm{~mm})$. These cubes were obtained from cylinders used during the microstructural evaluation. The results from the cubes were corrected by size and shape. For this purpose, the conversion factors for size and shape for normal-strength concrete proposed by SeongTae et al. (22) were implemented.

\section{RESULTS AND DISCUSSION}

\subsection{Chemical and physical properties of the selected UtSCBA}

Chemical analysis of the selected UtSCBA (Table 2) shows that the sum of major oxides $\left(\mathrm{SiO}_{2}+\mathrm{Al}_{2} \mathrm{O}_{3}+\mathrm{Fe}_{2} \mathrm{O}_{3}=76 \%\right)$ is slightly larger than $70 \%$ of the overall material composition (ASTM C 618); this result along with the SAI estimate corroborates the pozzolanic activity of the UtSCBA despite the high loss on ignition (LOI) content.

The analysis of the physical characteristics shows that the UtSCBA has lower density, greater mean PSD and larger SSA than the CPC (Table 3).

Figure 2a shows the PSDs for CPC and UtSCBA. It can be observed that the UtSCBA has a PSD between 3.8 and $250 \mu \mathrm{m}$ and CPC between 0.7 and $400 \mu \mathrm{m}$. The results indicate that UtSCBA has larger size particles when compared to CPC.

A detailed analysis of the PSD of these materials can be done analyzing their density distributions (Figure 2b). UtSCBA shows a monodisperse distribution, which can be associated with a sieved material (23). On the other hand, it can be observed that for the CPC the PSD shows two particle populations (bimodal) at 7 and $30 \mu \mathrm{m}$. This type of distribution

TABLE 1. Proportions of mortar mixtures $\left(\mathrm{kg} / \mathrm{m}^{3}\right)$

\begin{tabular}{lccccc}
\hline Mixture & Cement, $\mathbf{k g}$ & UtSCBA, $\mathbf{k g}$ & Water, $\mathbf{k g}$ & Sand, $\mathbf{k g}$ & HRWR, $\mathbf{m L} / \mathbf{k g}$ of cementitious materials \\
\hline Control & 465.0 & 0 & 293.0 & 1395.0 & 0 \\
UtSCBA10 & 418.5 & 46.5 & 293.0 & 1395.0 & 2.0 \\
UtSCBA20 & 372.0 & 93.0 & 293.0 & 1395.0 & 6.5 \\
\hline
\end{tabular}

HRWR: high range water reducer.

TABLE 2. Chemical composition of materials used in mortars ( $\%$ by mass)

\begin{tabular}{lccccccccc}
\hline Material & $\mathbf{S i O}_{2}$ & $\mathbf{A l}_{2} \mathbf{O}_{3}$ & $\mathbf{F e}_{2} \mathbf{O}_{3}$ & $\mathbf{C a O}$ & $\mathbf{P}_{2} \mathbf{O}_{\mathbf{5}}$ & $\mathbf{N a}_{\mathbf{2}} \mathbf{O}$ & $\mathbf{K}_{\mathbf{2}} \mathbf{O}$ & $\mathbf{M g O}$ & $\mathbf{L O I}$ \\
\hline CPC & 23.86 & 5.77 & 2.19 & 50.76 & 0.12 & 0.91 & 0.92 & 1.36 & 6.97 \\
UtSCBA & 56.37 & 14.61 & 5.04 & 2.36 & 0.85 & 1.57 & 3.29 & 1.43 & 10.53 \\
\hline
\end{tabular}

LOI: Loss on ignition. 
TABLE 3. Physical characteristics of materials

\begin{tabular}{lcccccc}
\hline Material & $\begin{array}{c}\text { Density } \\
\left(\mathbf{g} / \mathbf{c m}^{\mathbf{3}}\right)\end{array}$ & $\mathbf{D}_{\mathbf{1 0}}(\boldsymbol{\mu \mathbf { m } )}$ & $\mathbf{D}_{\mathbf{5 0}}(\boldsymbol{\mu \mathbf { m } )}$ & $\mathbf{D}_{\mathbf{9 0}}(\boldsymbol{\mu \mathbf { m } )}$ & $\begin{array}{c}\text { BET specific surface area } \\
\left(\mathbf{m}^{\mathbf{2}} / \mathbf{g}\right)\end{array}$ & $\begin{array}{c}\text { Retained in the mesh } \\
\mathbf{3 2 5} \mathbf{A S T M}(\mathbf{\%})\end{array}$ \\
\hline CPC & 2.94 & 2.9 & 16.3 & 55.2 & 3.6 & - \\
UtSCBA & 2.19 & 13.9 & 40.3 & 87.3 & 42.3 & 60 \\
\hline
\end{tabular}
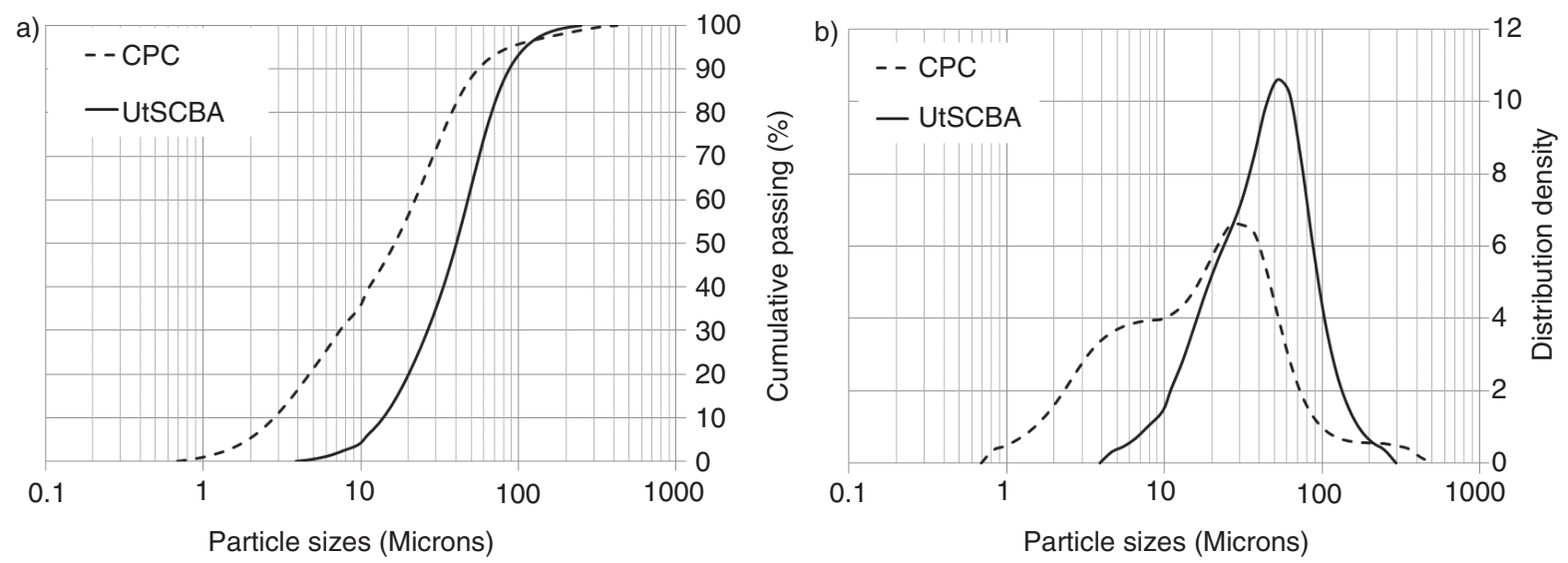

FIGURE 2. Particle-size distribution of materials.

can be caused by two factors: the presence of particles from the different mineralogical components because a compound cement was used (13), and the result of grinding because fine particles tend to cluster (7).

The UtSCBA show grains of varied shapes and sizes in accordance with the calcination conditions (Figure 3) $(12,24)$. There are agglomerated particles with high porosity, typical for organic materials, and prismatic particles with well-defined edges (9,25-26). The EDS microanalysis revealed that the agglomerated particles (A) are rich in $\mathrm{Si}, \mathrm{Al}$ and $\mathrm{C}$ oxides and not so rich in $\mathrm{Ca}$ oxides (8). The prismatic particles (B) are constituted mostly by $\mathrm{Si}$. Furthermore, spherical (C) and fibrous carbon particles (unburned carbon) (D) were observed. The spherical particles are rich in $\mathrm{Ca}$ and $\mathrm{Si}$ oxides as well as $\mathrm{Al}$ and $\mathrm{Fe}$, and the fibrous particles contain mainly $\mathrm{Si}$ and $\mathrm{Al}$. In this respect, recent studies (27) found that some fibrous carbon particles from SCBA may be covered by Si and O depending on the pyrolysis of the bagasse, affirming that the unburned carbon can present amorphicity.

In summary, the high LOI, lower density, greater PSD, larger SSA (in comparison with CPC), simultaneous appearance of amorphous and crystalline phases, and variability of the the UtSCBA's shapes and sizes can be attributed to the variations of temperature and air flow during the bagasse's calcination process in the sugar mill, in accordance with results observed by other authors (24).

The results of the XRD mineralogical analyses show that the CPC (Figure 4a) contains mainly di-calcium and tri-calcium silicate, tri-calcium aluminate and tetra-calcium aluminoferrite, and to a lesser extent calcium oxide, calcium carbonate and gypsum. The results of the XRD mineralogical analyses (Figure 4b) show that the UtSCBA exhibited amorphous and crystalline phases. The amorphous phase in the UtSCBA was observed as a diffuse halo in the interval $2 \theta$ from $10^{\circ}$ to $35^{\circ}$. This halo, which is characteristic of pozzolanic materials, suggests the presence of amorphous substances such as silica $(6,8,15,24,28-29)$. The crystalline phases of quartz and cristobalite in the UtSCBA were detected; both phases have been reported by others $(6,25,29)$. Also gibbsite $\left(\mathrm{Al}_{2} \mathrm{O}_{3}\right)$, hematite $\left(\mathrm{Fe}_{2} \mathrm{O}_{3}\right)$ and calcium $(\mathrm{Ca})$ phases were identified, and the residual carbon (C) phase in the UtSCBA, commonly attributed to the bagasse's LOIs $(8,13)$, was detected at $2 \theta$ of $22.8^{\circ}$ and $26.6^{\circ}$. However, the identification of carbon in the crystalline phase was little reliable due to the small quantity as well as the overlapping observed in the signal.

\subsection{Properties in fresh state of mortars}

Mortars prepared with UtSCBA presented workability problems which were overcome with a superplasticizer, as previously demonstrated in the section on the proportioning of the mortar mixture. The high LOI content, an indication of the high level of unburned carbon particles, can be blamed for this. Chandara et al. (30) mentioned that high levels of unburned carbon particles increase the requirement 


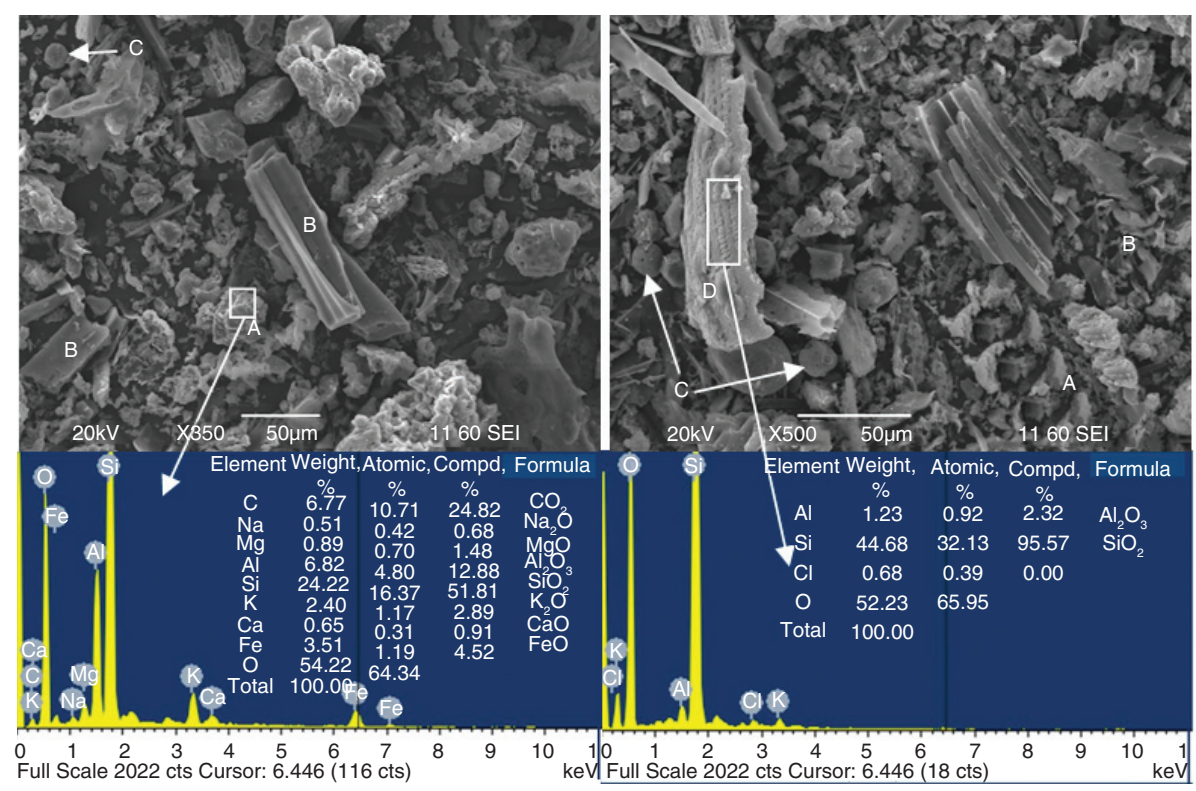

FIGURE 3. SEM micrographs and elemental analysis of the UtSCBA used in the present study. $\mathrm{A}$ is an agglomerated particle, $\mathrm{B}$ a prismatic, $\mathrm{C}$ a spherical, and $\mathrm{D}$ a fibrous.
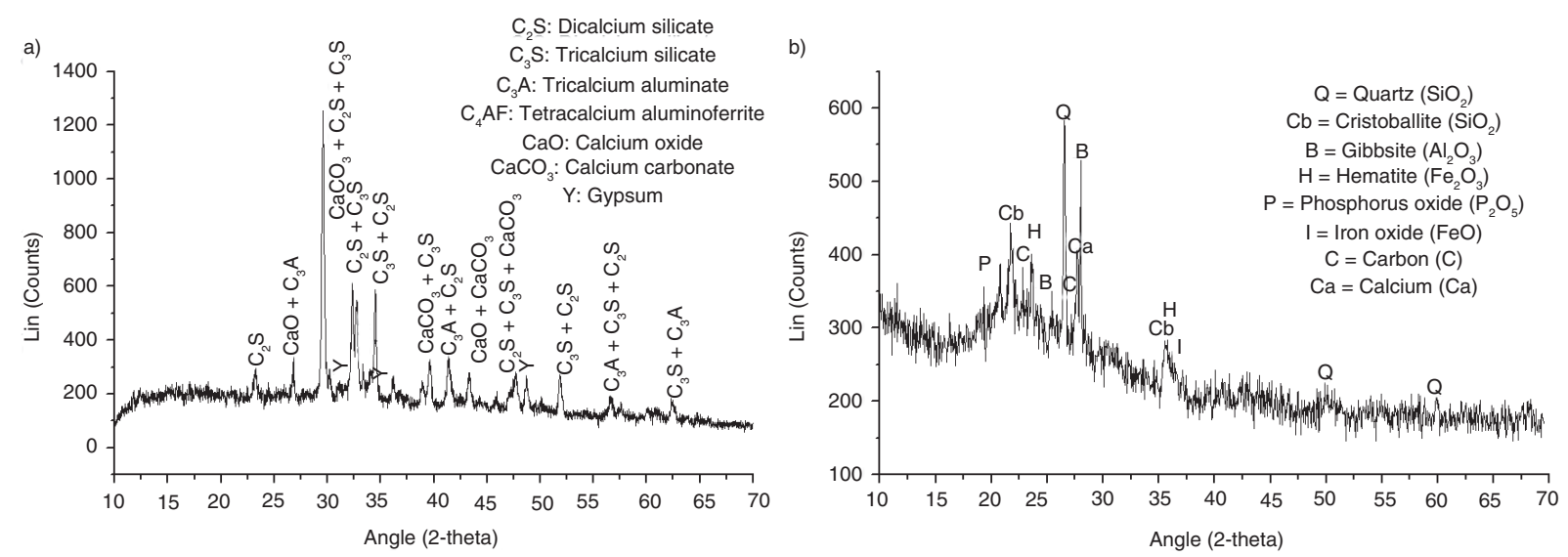

FIgURE 4. XRD diagrams for the a) CPC and the b) UtSCBA used in the present study.

for water, and Jiménez-Quero et al. (31) reported that the variety of shapes of sieved UtSCBA particles can reduce the flow of the mortar mixtures since these particles can increase friction during the mixing process.

Mortar with 20\% UtSCBA was less dense than the other mortars (Table 4). This was expected, as UtSCBA is a porous material with a lower density, greater mean PSD, and larger SSA than CPC.

\subsection{Microstructure of mortars}

The micrograph of the control mortar at day 1 shows a heterogeneous matrix. The phases of $\mathrm{C}-\mathrm{S}-\mathrm{H}$ and $\mathrm{CH}$ created from the Portland cement hydration were found to be in the majority of the cementitious products (32-33). At 1 and 7 days, unhydrated particles of cement and particles with layers of hydration products were observed (Figures 5a and 5b) (32-34). Moreover, discontinuities in the interphase aggregate-cementitious paste were observed (Figure 5a) at day 1. At 28, 90 and 600 days the matrix of the mortars was denser (Figures 5c, 5d and 5e); nevertheless, porous zones with cementitious materials and cement particles were still observed.

Similarly to the control mortar, micrographs of mortars containing 10 and $20 \%$ UtSCBA taken at day 1 (Figures 6a and 7a) show some cement particles, unreacted particles of UtSCBA and some cementitious products on the surface of the UtSCBA particles. The EDS microanalyses (Figure 6a) show the different elements on the surface of a prismatic particle of UtSCBA. In UtSCBA mortars it 
The influence of untreated sugarcane bagasse ash on the microstructural and mechanical properties of mortars $\bullet$

TABLE 4. Fresh properties of mortars

\begin{tabular}{lcccc}
\hline Mixture & Flow (\%) & Temperature $\left({ }^{\circ} \mathbf{C}\right)$ & Volumetric weight $\left(\mathbf{K g} / \mathbf{m}^{\mathbf{3}}\right)$ & Air content $(\mathbf{\%})$ \\
\hline Control & 118 & 22.5 & 2100 & 2.80 \\
UtSCBA10 & 104 & 20.3 & 2096 & 2.65 \\
UtSCBA20 & 105 & 20.2 & 2072 & 3.4 \\
\hline
\end{tabular}
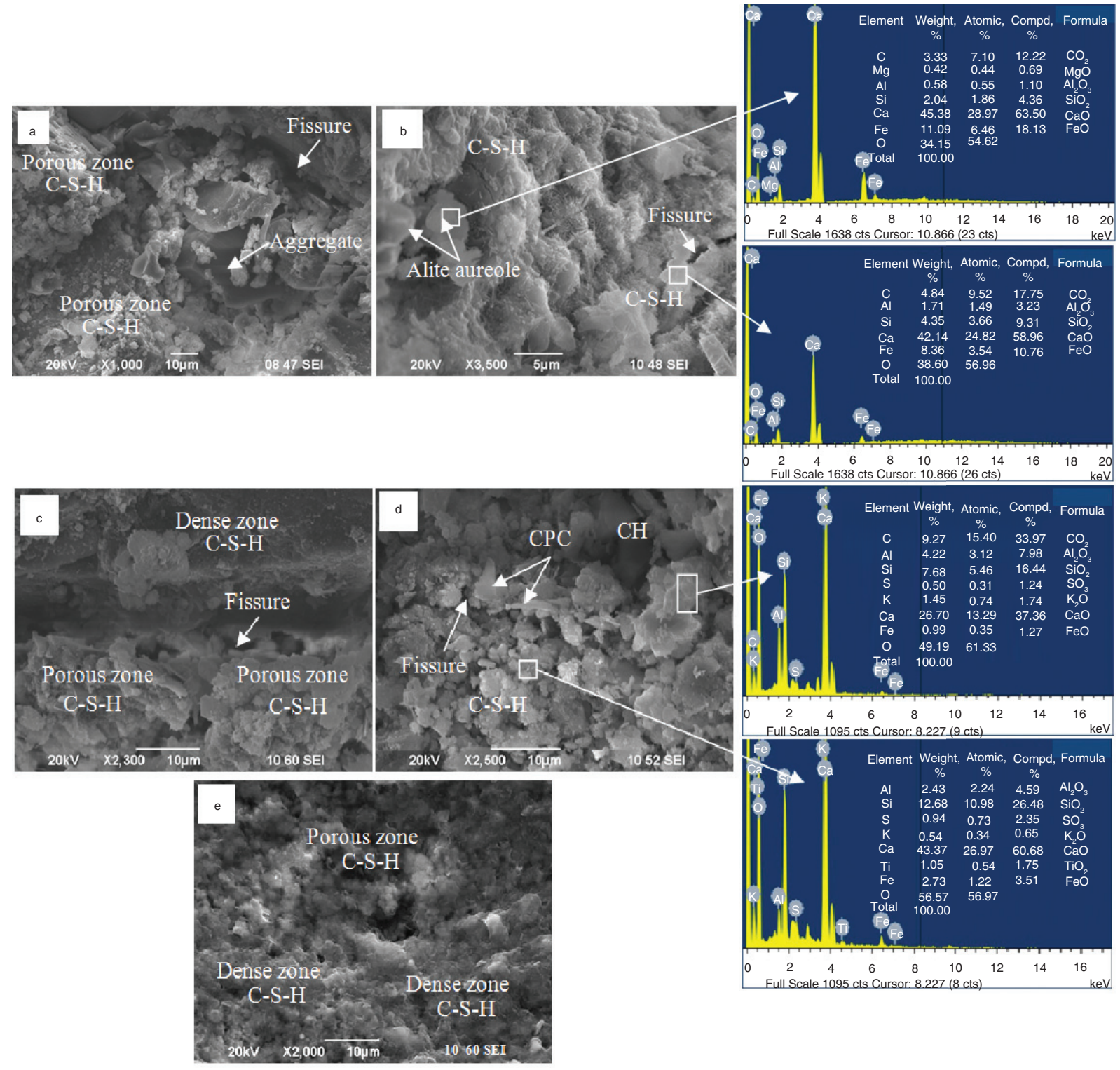

Figure 5. SEM observations of control mortar at A) 1, B) 7, C) 28, D) 90 and E) 600 days of age.

was observed that as time passes, the cementitious matrixes were denser than the control mortar. The same effect was found by Govindarajen et al. (35) in cement pastes with $10 \%$ SCBA evaluated at 7 and 28 days, and in concrete when up to $30 \%$ SCBA was added and evaluated until 180 days of age (36).

The information mentioned above supports the occurrence of pozzolanic reactions as a consequence of the $\mathrm{CH}$ consumption and the formation of $\mathrm{C}-\mathrm{S}-\mathrm{H}$ and calcium-aluminum silicate hydrate (C-A-S-H) (Figures 6b, 6c, 6d, 6e, 7b, 7c, 7d and 7e) improving in this way compressive strength at later ages. However, at 90 days unreacted prismatic particles of UtSCBA were observed (Figure 6d) in the UtSCBA10 mortar; these particles were the largest in size and could improve the cementitious matrix 


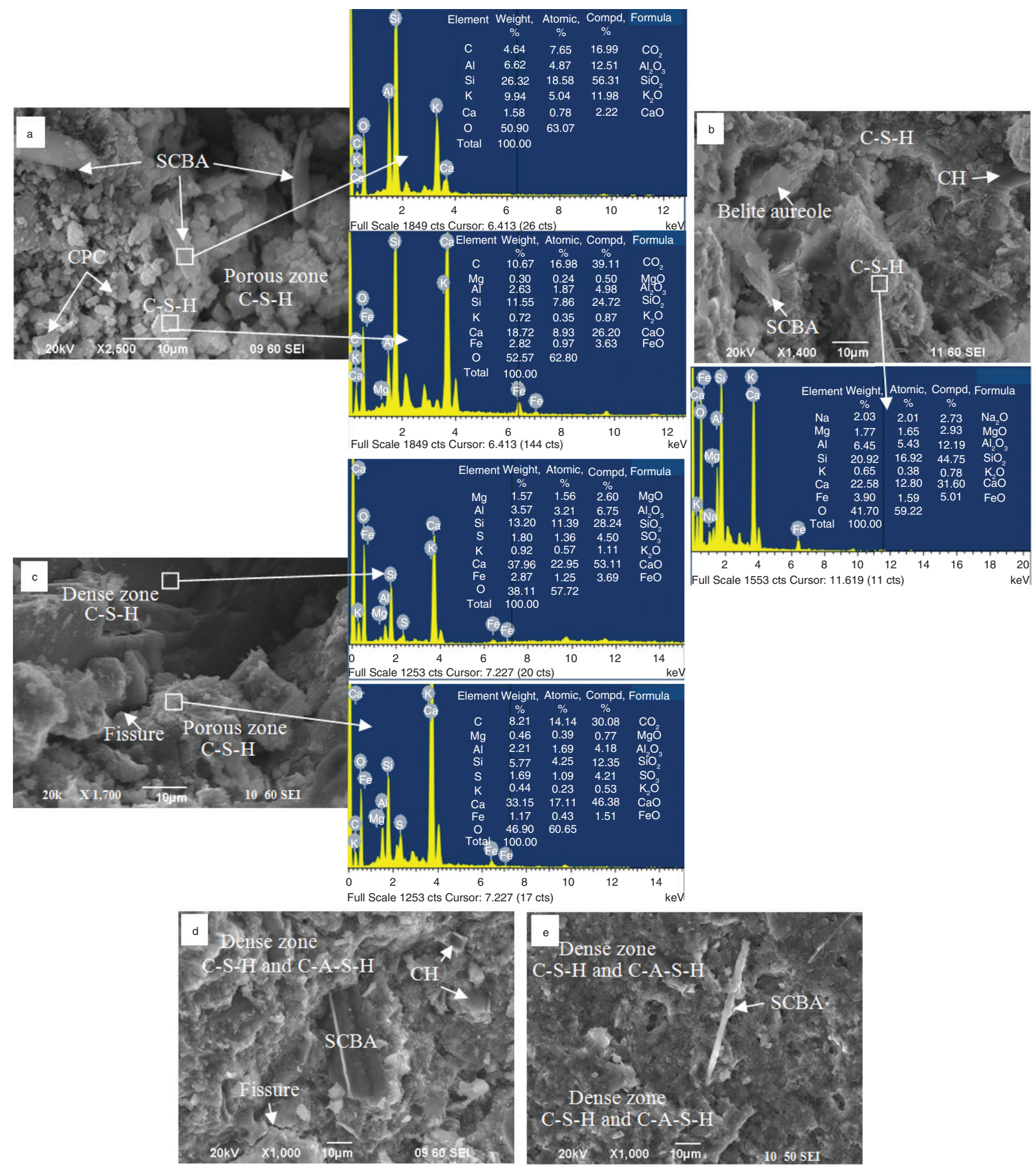

Figure 6. SEM observations of UtSCBA10 mortar at A) 1, B) 7, C) 28, D) 90 and E) 600 days of age.

at later stages. Finally, at 600 days it can be seen as a compacted matrix in both UtSCBA mortars when compared to earlier ages.

\subsection{Mineralogical composition of mortars}

The XRD patterns of the control mortar (Figure 8) show that the C-S-H $\left(4 \mathrm{CaO} .5 \mathrm{SiO}_{2} .5 \mathrm{H}_{2} \mathrm{O}\right)$ and $\mathrm{CH}\left(\mathrm{Ca}(\mathrm{OH})_{2}\right)$ were the main mineralogical phases formed; both phases were produced during the Portland cement hydration. At day 1 the phase of calcium silicate $\left(\mathrm{CaSiO}_{3}\right)$, attributed to unhydrated particles in the cement, was detected; at later ages the intensity of the peaks of this phase decreased. At 28, 90 and 600 days a phase of C-S-H with different stoichiometry $\left(\mathrm{CaSiO}_{3} \cdot \mathrm{H}_{2} \mathrm{O}\right)$ and the phase of C-A$\mathrm{S}-\mathrm{H}\left(\mathrm{CaAl}_{2} \mathrm{Si}_{3} \mathrm{O}_{10} 6 \mathrm{H}_{2} \mathrm{O}\right)$ were detected. The appearance of two or more phases of C-S-H is known and 

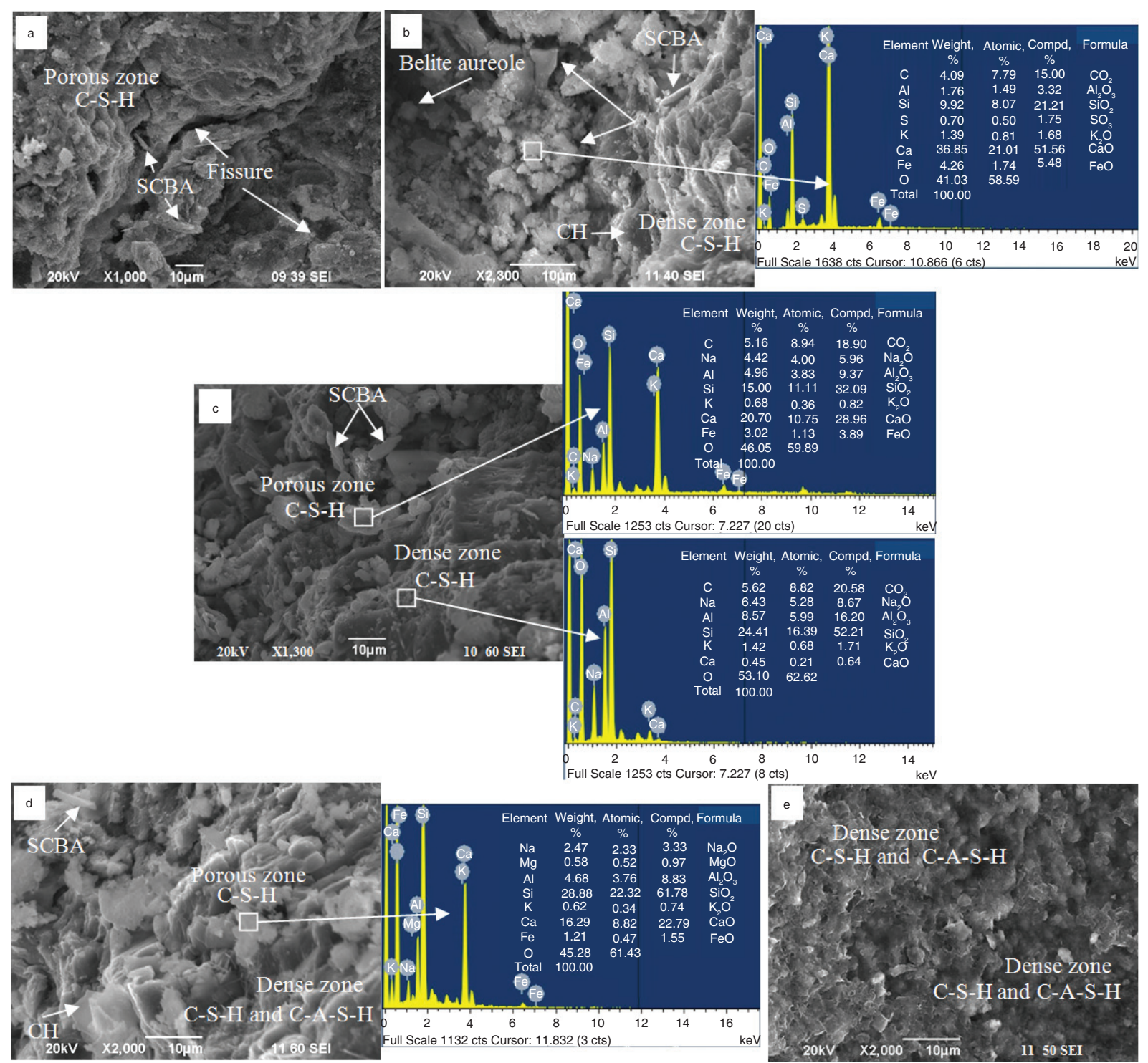

FIgURE 7. SEM observations of UtSCBA20 mortar at A) 1, B) 7, C) 28, D) 90, and E) 600 days of age.

reported by other authors $(32,37-38)$. The C-A-S-H is a product formed after activation of the aluminate and silicate phases in the presence of $\mathrm{CH}$ and could improve the microstructure and increase the durability of mortars (38). Other phases like quartz $\left(\mathrm{SiO}_{2}\right)$ and anorthite attributed to the sand, and Calcite $\left(\mathrm{CaCO}_{3}\right)$ attributed to the $\mathrm{CPC}$, were also detected.

The XRD patterns of the UtSCBA10 and UtSCBA20 mortars (Figures 9 and 10) show the increase of the peak intensities of the C-S-H and $\mathrm{C}-\mathrm{A}-\mathrm{S}-\mathrm{H}$ phases on the mortars as age progressed. Both products were created as the result of pozzolanic reactions between the UtSCBA, $\mathrm{CH}$ and water; this observation is supported by the decreased intensity of the $\mathrm{CH}$ phase and the increase of the C-S-H phase in comparison to the control mortar, as observed at 28,90 and 600 days. The consumption of $\mathrm{CH}$ and the increase of the C-S-H in lime and cement pastes with the addition of SCBA at ages between 3 and 28 days has been reported $(25,35)$.

In the present research, when $10 \%$ of cement is replaced by UtSCBA a pozzolanic reaction occurs and $\mathrm{CH}$ still remains in the matrix until the active material in the pozzolan is depleted. When $20 \%$ cement is replaced by UtSCBA, the $\mathrm{CH}$ is once again consumed but at a slower rate than for 10\% UtSCBA. In this mixture there is a larger amount of silica present but also a larger amount of carbon, and carbon can be blamed for significantly inhibiting the pozzolanic reaction (25). When $20 \% \mathrm{UtSCBA}$ is incorporated there is still a considerable amount of $\mathrm{CH}$ because only a very large replacement of cement by a pozzolan depletes the $\mathrm{CH}$ content. For example, when more than $50 \%$ FA is used to replace cement the $\mathrm{CH}$ is totally consumed (39). 

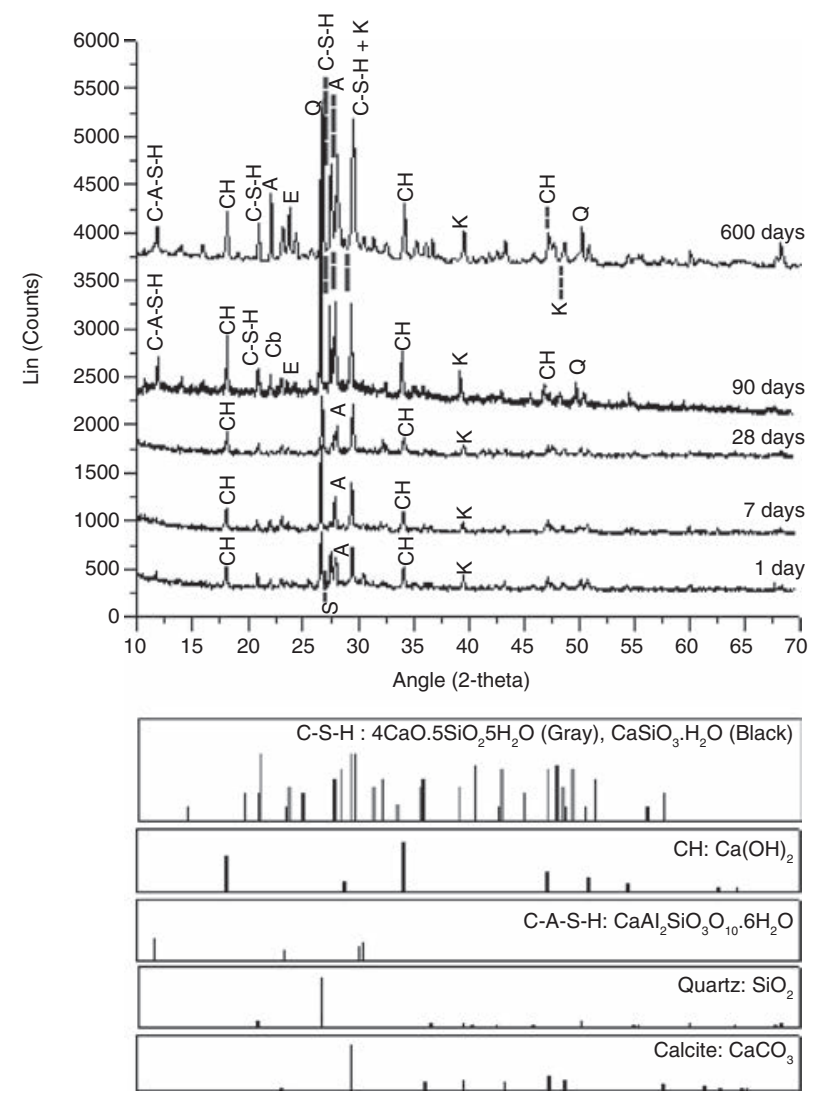

FIGURE 8. XRD patterns of control mortar at 1, 7, 28, 90 and 600 days of age. C-S-H: calcium silicate hydroxide; $\mathrm{CH}$ : calcium hydroxide; C-A-S-H: calcium aluminum silicate hydrate;

Q: quartz, K: calcite; E: ettringite; A: anorthite; S: calcium silicate; and $\mathrm{Cb}$ : cristobalite.

The above mentioned information and the physical characteristics of the UtSCBA explain the increase in the compressive strength of mortars with the addition of UtSCBA at later ages.

Moreover, the phase of cristobalite showed variations at different ages. These variations can be attributed to the disordered structures or its metastable state, which could improve pozzolanicity (40-41).

\subsection{Compressive strength of mortars}

Compressive strength of the mortar mixtures containing UtSCBA increased over time. The addition of 10 and 20\% UtSCBA (UtSCBA10 and UtSCBA20) increased the strength at 28, 56, 90, 450 and 600 days when compared to the control mortar (Figure 11). However, the beneficial effect on the strength when adding UtSCBA was noted only after 28 days. The same effect was observed by other authors when ground SCBA was used in concrete mixtures (36).

Moreover, it was observed that when the content of UtSCBA increased from 10 to $20 \%$, the compressive
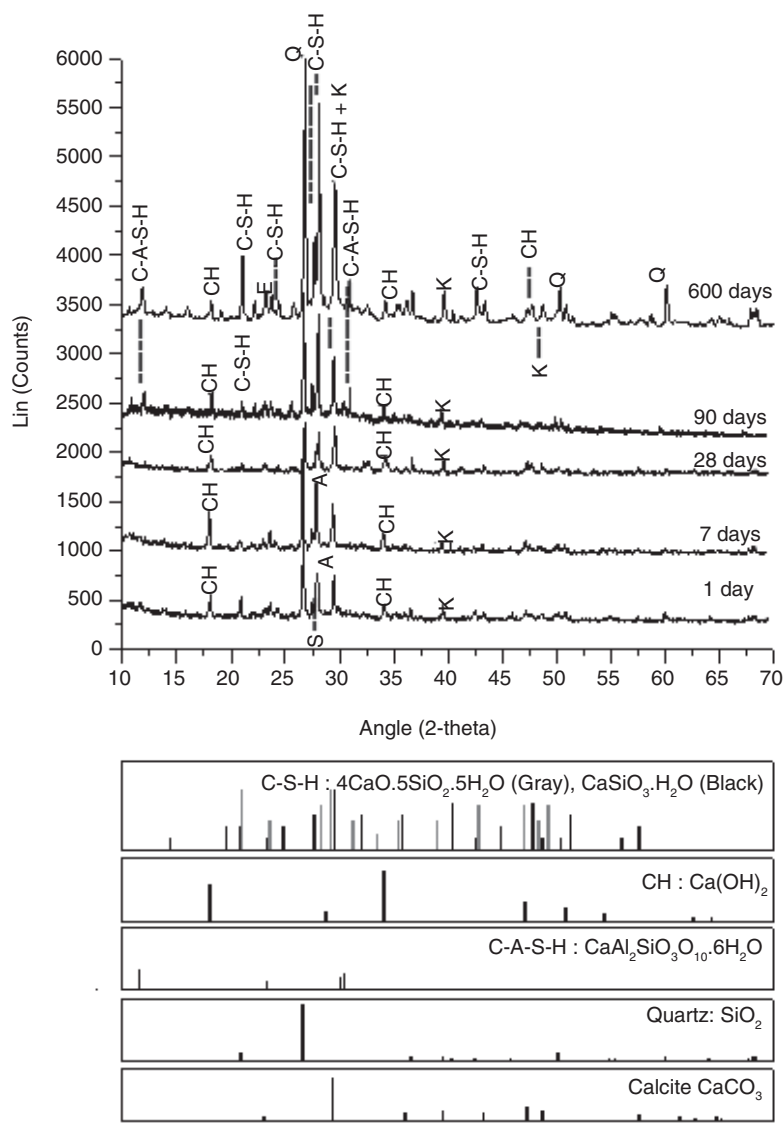

FIGURE 9. XRD patterns of UtSCBA10 mortar at 1, 7, 28, 90 and 600 days of age. C-S-H: calcium silicate hydroxide;

$\mathrm{CH}$ : calcium hydroxide; $\mathrm{C}-\mathrm{A}-\mathrm{S}-\mathrm{H}$ : calcium aluminum silicate hydrate; Q: quartz; K: calcite; E: ettringite; A: anorthite; and $\mathrm{S}$ : calcium silicate.

strength at 1, 7, 28, 56 and 90 days decreased between 7 and $12 \%$. Chusilp et al. (11) reported this effect in mortars with ground bagasse ash and 10\% LOI (similar to the LOI obtained in this research). In contrast, compressive strength results at 450 and 600 days show that when the content of UtSCBA increased from 10 to $20 \%$ in mortars mixtures, a slight increase in strength occurred. Results show that the addition of $20 \%$ UtSCBA increased the compressive strength by $10.6 \%$ and $11.2 \%$ at 450 and 600 days respectively compared with the compressive strength at 90 days, while the mortar with addition of $10 \%$ UtSCBA remains practically constant at 90, 450 and 600 days. In this respect, Chusilp et al. (16) reported a similar behavior using 10 and 20\% ground SCBA $(95 \%$ of the ash passing the No. 325 sieve and LOI of $8.16 \%$ ) in concrete mixtures at 28 and 90 days, in which the compressive strength of the concrete with the addition of $20 \%$ SCBA was greater than that of the concrete with the addition of $10 \%$ SCBA.

The above mentioned could be attributed to the fact that after 90 days the UtSCBA20 mortar has 

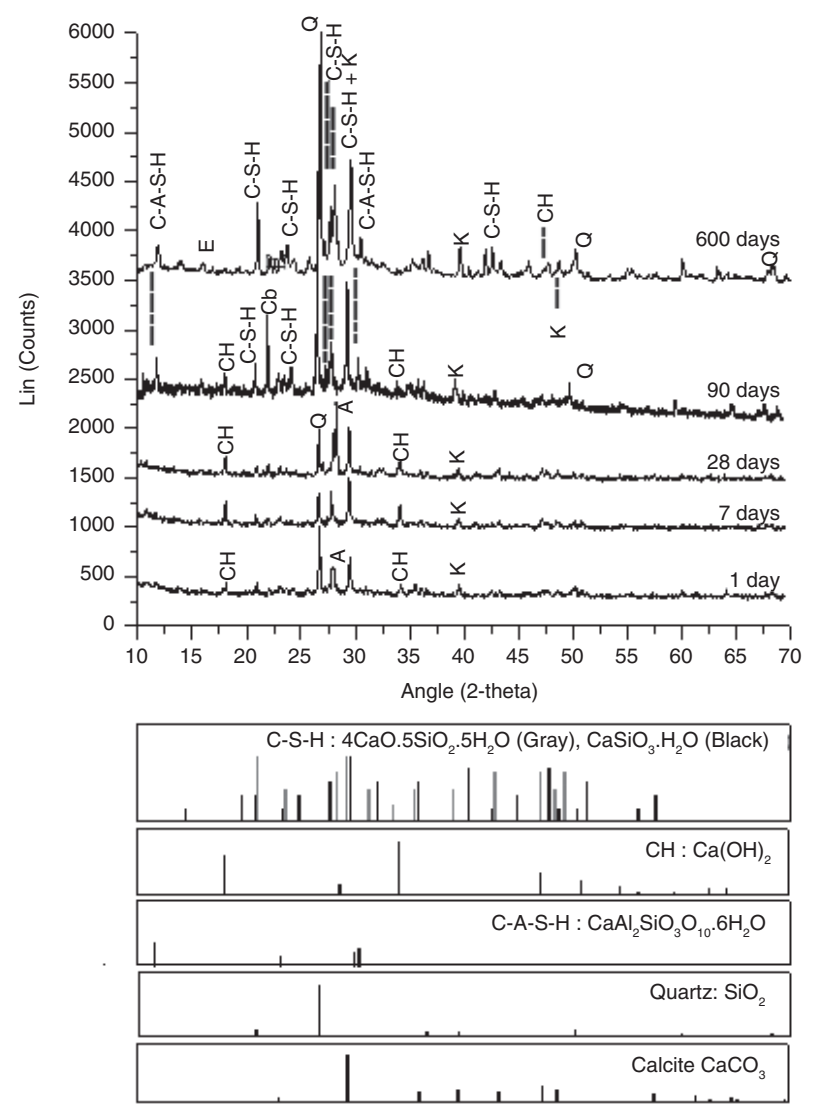

FIGURE 10. XRD patterns of UtSCBA20 mortar at 1, 7, 28, 90 and 600 days of age. C-S-H: calcium silicate hydroxide; $\mathrm{CH}$ : calcium hydroxide; C-A-S-H: calcium aluminum silicate hydrate; Q: quartz; K: calcite; E: ettringite; A: anorthite; and $\mathrm{Cb}$ : cristobalite.

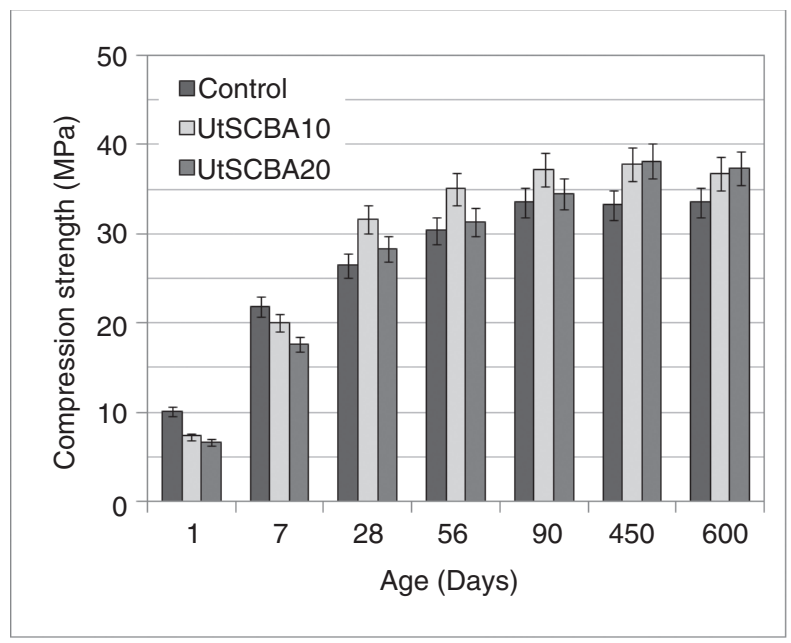

FIGURE 11. Compressive strength of mortars.

more unreacted UtSCBA, which improves the pozzolanic activity in comparison with the UtSCBA10 mortar. Likewise, the large fibrous-porous particles of UtSCBA (which are covered with a layer of $\mathrm{Si}$ and $\mathrm{O}$ ), as well as the small particles, increase the specific surface area for the pozzolanic activity; consequently there is a gain in strength when $20 \%$ UtSCBA is added to the mortar.

The results indicate that, despite using a basically untreated SCBA as a cement replacement for preparing mortars, ash like this helps improve the longterm compressive strength and the microstructure of such mortars.

\section{CONCLUSIONS}

Based on the analysis of results, the following conclusions can be drawn:

- The SAIs results show that, for this research, the sieving of the "as received SCBA" through the No. $200(75 \mu \mathrm{m})$ mesh (ASTM) is an optimal treatment with minimum energy requirements in comparison to other treatments such as grinding or sieving plus grinding. This treatment leads to a good pozzolanic performance of the "as received" SCBA due to the removal of large unburnt carbon particles and the reduction of particle size.

- Results of XRD show that the UtSCBA (sieved through the $75 \mu \mathrm{m}$ ASTM mesh) is a good pozzolanic material due to the presence of amorphous phases observed in the interval $2 \theta$ from $10^{\circ}$ to $35^{\circ}$. Likewise, the micrographs of the UtSCBA suggest that the fibrous carbon particles can react since they have a layer of $\mathrm{Si}$ and $\mathrm{O}$ on their surfaces.

- Compressive strength results show that the additions of 10 and $20 \%$ UtSCBA increase the strength of mortars at ages between 28 and 600 days. Furthermore, results show that the compressive strength of the mortar with $10 \%$ UtSCBA is greater than the mortar with $20 \%$ UtSCBA at ages of 1, 7, 28, 56 and 90 days. This was reversed at 450 and 600 days. This suggests that the optimum fraction of UtSCBA replacing cement in mortars is $10 \%$ by weight of cement.

- Results indicate that the addition of 10 and 20\% UtSCBA significantly improved the microstructure of the mortars by the refinement of pore structure and a denser matrix in comparison to the control mortar, especially at 28, 90 and 600 days, despite the large particle-size distribution, porous particles and high LOI presented in the UtSCBA.

- Results in the compressive strength and microstructural evaluations at long-term ages show that the use of 10 and $20 \%$ UtSCBA as a replacement for cement might improve the durability of mortars. In this respect, long-term durability studies using UtSCBA have been addressed in ongoing research. 


\section{ACKNOWLEDGMENTS}

The authors are grateful to the Instituto Politécnico Nacional of México for the financial support provided during the development of this research. The authors also appreciate the support provided by the staff of the Instituto de Ingeniería Civil of the Universidad Autónoma de Nuevo León as most of the microstructural characterization of the materials and mortars was carried out there. Furthermore, the authors thank to the Consejo Nacional de Ciencia y Tecnología (CONACyT) of Mexico for the doctoral scholarship granted to Marco A. Maldonado-García.

\section{REFERENCES}

1. Worrell, E.; Price, L.; Martín, N.; Hendriks, C.; Ozawa, M.L. (2001) Carbon dioxide emissions from the global cement industry. Annu. Rev. Energy Environ. 26, 303-329. https://doi.org/10.1146/annurev.energy.26.1.303

2. Hendriks, C.A.; Worrell, E.; de Jager, D.; Blok, K.; Riemer, P. (2004) Emission reduction of greenhouse gases from the cement industry. Greenhouse gas control technologies Conference paper-cement. www.ieagreen.org.uk

3. International Energy Agency (IEA). Carbon emissions reduction up to 2050. World Business Council for Sustainable Development. Cement Technology Roadmap 2009. https:// www.iea.org/publications/freepublications/publication/ Cement.pdf

4. Cement Industry Federation (CIF). Sustainability Report 2011. www.cement.org.au

5. Josa, A.; Aguado, A.; Cardim, A.; Byars, E. (2007) Comparative analysis of the cycle impact assessment of available cement inventories in the EU. Cem. Concr. Res. 37 [5], 781-788. https://doi.org/10.1016/j.cemconres.2007.02.004

6. Ganesan, K.; Rajagopal, K.; Thangavel, K. (2007) Evaluation of bagasse ash supplementary cementitious material. Cem. Concr. Comp. 29 [6], 515-524. https://doi. org/10.1016/j.cemconcomp.2007.03.001

7. Cordeiro, G.C.; Toledo-Filho, R.D.; Tavares, L.M.; Fairbairn, E.M.R. (2008) Pozzolanic activity and filler effect of sugar cane bagasse ash in Portland cement and lime mortars. Cem. Concr. Comp. 30 [5], 410-418. https:// doi.org/10.1016/j.cemconcomp.2008.01.001

8. Morales, E.V.; Villar-Cociña, E.; Frías, M.; Santos, S.F.; Savastano, J.R.H. (2009) Effects of calcining conditions on the microstructure of sugar cane waste ashes (SCWA): Influence in the pozzolanic activation. Cem. Concr. Comp. 31 [1], 22-28. https://doi.org/10.1016/j. cemconcomp.2008.10.004

9. Cordeiro, G.C.; Toledo-Filho, R.D.; Fairbairn, E.M.R. (2009)a Effect of calcination temperature on the pozzolanic activity of sugar cane bagasse ash. Construct. Build. Mat. 23 [10], 3301-3303. https://doi.org/10.1016/j. conbuildmat.2009.02.013

10. Cordeiro, G.C.; Toledo-Fhilo, R.D.; Tavares, L.M.; Fairbair, E.M.R. (2009)b Ultrafine grinding of sugar cane bagasse ash for application as pozzolanic admixture in concrete. Cem. Concr. Res. 39 [2], 110-115. https://doi. org/10.1016/j.cemconres.2008.11.005

11. Chusilp, N.; Jaturapitakkul, C.; Kiattikomol, K. (2009) a Effects of LOI of ground bagasse ash on the compressive strength and sulfate resistance of mortars. Construct. Build. Mat. 23 [12], 3523-3531. https://doi.org/10.1016/j. conbuildmat.2009.06.046

12. Bahurudeen, A.; Santhanam, M. (2015) Influence of different processing methods on the pozzolanic performance of sugarcane bagasse ash. Cem. Concr. Comp. 56, 32-45. https://doi.org/10.1016/j.cemconcomp.2014.11.002
13. Frías, M.; Villar, E.; Svastano, H. (2011) Brazilian sugar cane bagasse ashes from the cogeneration industry as active pozzolans for cement manufacture. Cem. Concr. Comp. 33, 490-496. https://doi.org/10.1016/j.cemconcomp.2011.02.003

14. Dhengare S.; Amrodiya S.; Shelote M.; Asati A.; Bandwaf N.; Anand K.; Jichkar. (2015) Utilization of sugarcane bagasse ash as a supplementary cementitious material in concrete and mortar - a review. International Journal of Civil Engineering and Technology. 6 [4], 94-106. http://www.iaeme.com/ijciet/ index.asp

15. Valencia, G.; Mejía de Gutierrez, R.; Barrera, J.; Delvasto, S. (2012) Estudio de durabilidad y corrosión en morteros armados adicionados con toba volcánica y ceniza de bagazo de caña de azúcar. Revista de la Construcción. 12 [22], 112-122. https://doi.org/10.4067/S0718-915X2012000200010

16. Chusilp, N.; Jaturapitakkul, C.; Kiattikomol, K. (2009)b Utilization of bagasse ash as a pozzolanic material in concrete. Construct. Build. Mat. 23 [11], 3352-3358. https://doi. org/10.1016/j.conbuildmat.2009.06.030

17. Unión Nacional de Cañeros A. C. de México. (2016). Viewed on July $13^{\text {th }} 2016$, www.caneros.org.mx

18. Akram, T.; Memon, S.A.; Obaid, H. (2009) Production of low-cost self-compacting concrete using bagasse ash. Construct. Build. Mat. 23 [2], 703-712. https://doi. org/10.1016/j.conbuildmat.2008.02.012

19. Villar-Cociña, E.; Valencia-Morales, E.; Gonzáles-Rodriguez, R,; Hernández-Ruiz, J. (2003) Kinetics of the pozzolanic reaction between lime and sugar cane straw ash by electrical conductivity measurement: A kinetic-diffusive model. Cem. Concr. Res. 33 [4], 517-524. https://doi.org/10.1016/ S0008-8846(02)00998-5

20. Frías, M.; Villar-Cociña, E.; Sanchez de Rojas, M.I.; Valencia-Morales, E. (2005) The effect that different pozzolanic activity methods has on the kinetic constants of the pozzolanic reaction in sugar cane straw-clay ash/ lime systems: Application of a diffusive model. Cem. Concr. Res. 35 [11], 2137-2142. https://doi.org/10.1016/j. cemconres.2005.07.005

21. Bahurudeen, A.; Wani K.; Abdul B.M.; Santhanam, M. (2016) Assessment of pozzolanic performance of sugarcane bagasse ash. J. Mater. Civ. Eng. 28[2], 01-11. https://ascelibrary.org/doi/10.1061/\%28ASCE\%29MT. 1943-5533.0001361

22. Seong-Tae Y.; Eun-Ik Y.; Joong-Cheol C. (2006) Effect of specimen sizes, specimen shapes, and placement directions on compressive strength of concrete. Nuclear Engineering and Design 236 [2], 115-127. https://doi.org/10.1016/j. nucengdes.2005.08.004

23. German, R M. (1994) Powder metallurgy Science. MPIF Princeton. USA, (1994).

24. Soares, M.M.N.S.; Poggiali, F.S.J.; Bezerra, A.C.S.; Figueiredo, R.B.; Aguilar, M.T.P.; Catlin, P.R. (2014) The effect of calcination conditions on the physical and chemical characteristics of sugar cane bagasse ash. REM: R. Esc. Minas, Ouro Petro. 67(1), 33-39. https://doi.org/10.1590/ S0370-44672014000100005

25. Martirena, J.F.; Middendor, F.B; Gehrke, M; Budelmann, H. (1998) Use of wastes of the sugar industry in limepozzolana binders: Study of the reaction. Cem. Concr. Res. 28[11], 1525-1536. https://doi.org/10.1016/S0008-8846 (98)00130-6

26. Somna, R.; Jaturapitakkul, C.; Rattanachu, P.; Chalee, W. (2012) Effect of ground bagasse ash on mechanical and durability properties of recycled aggregated concrete. Materials and Design. 36, 597-603. https://doi. org/10.1016/j.matdes.2011.11.065

27. Batra, V.S.; Urbonaite, S.; Svensson, G. (2008) Characterization of unburned carbon in bagasse fly ash. Fuel. 87 [13-14], 2972-2976. https://doi.org/10.1016/j. fuel.2008.04.010

28. Martirena, F.; Middenford, B.; Day, R.L.; Gehrke, M.; Roque, P.; Martinez, L.; Betancourt S. (2006) Rudimentary, low-tech incinerators as a means to produce reactive pozzolan out of sugar cane straw. Cem. Concr. Res. 36 [6], 10561061. https://doi.org/10.1016/j.cemconres.2006.03.016 
29. Cordeiro, G.C.; Toledo Filho, R.D.; Tavares, L.M.; Fairbairn, E.M.R. (2012) Experimental characterization of binary and ternary blended-cement concretes containing ultrafine residual rice husk and sugar cane bagasse ashes. Construct. Build. Mat. 29, 641-646. https://doi. org/10.1016/j.conbuildmat.2011.08.095

30. Chandara, C.; Sakai, E.;Azizli, K.A.M.; Ahmad, Z.A.; Hashim, S.F.A. (2010) The effect of unburned carbon in palm oil fuel ash on fluidity of cement pastes containing superplasticizer. Construct. Build. Mat. 24 [9], 1590-1593. https://doi.org/10.1016/j.conbuildmat.2010. 02.036

31. Jímenez-Quero, V.G.; León-Martínez, F.M.; MontesGarcía, P.; Gaona-Tiburcio, C.; Chacón-Nava, J.G. (2013) Influence of sugar-cane bagasse ash and fly ash on the rheological behavior of cement pastes and mortars. Construct. Build. Mat. 40, 691-701. https://doi.org/10.1016/ j.conbuildmat.2012.11.023

32. Diamond, S. (2004) The microstructure of cement paste and concrete--a visual primer. Cem. Concr. Comp. 26 [8], 919933. https://doi.org/10.1016/j.cemconcomp.2004.02.028

33. Giraldo, M.A.; Tobón, J.I. (2006) Mineralogical evolution of Portland cement during hydration process. Dyna. 73 [148], 69-81. http://www.scielo.org.co/scielo.php?script $=$ sci arttext\&pid $=$ S0012-73532006000100007\&lng $=$ en\&nrm $=$ is o\&tlng=es

34. Torres, J.; Mejía de Gutiérrez, R.; Castelló, R.; Vizcaino, C. (2008) Proceso de hidratación depastas de OPC adicionadas con caolín tratado térmicamente. Revista Facultad de Ingeniería. Universidad de Antioquia. 43, 77-85. http:// www.scielo.org.co/pdf/rfiua/n43/n43a07.pdf
35. Govindarajan, D.; Jayalakshmi, G. (2011) XRD, FIRT and SEM studies on calcined sugarcane bagasse ash blended cement. Archives of Physics Research. 2 [4], 38-44. http:// scholarsresearchlibrary.com/APR-vol2-iss4/APR-2011-2-438-44.pdf

36. Hussein, A.A.E.; Shafiq, N.; Nuruddin, M.F.; Memon, F.A. (2014) Compressive strength and microstructure of sugar cane bagasse ash concrete. Research Journal of Applied Sciences, Engineering and Technology. 7 [12], 2569-2577. https://www.researchgate.net/publication/287501413 Compressive_Strength_and_Microstructure_of_Sugar_Cane_Bagasse_Ash_Concrete

37. Richardson, I.G. (2008) The calcium silicate hydrates. Cem. Concr. Res. 38 [2], 137-158. https://doi.org/10.1016/j. cemconres.2007.11.005

38. Arizzi, A.; Cultrone, G. (2012) Aerial lime-based mortars blended with a pozzolanic additive and different admixtures: A mineralogical, textural and physical-mechanical study. Construct. Build. Mat. 31, 135-143. https://doi. org/10.1016/j.conbuildmat.2011.12.069

39. Sisomphon, K.; Franke, L. (2011) Evaluation of calcium hydroxide contents in pozzolanic cement pastes by a chemical extraction method. Construct. Build. Mat. 25 [1], 190-194. http://doi.org/10.1016/j.conbuildmat.2010. 06.039

40. Valdez-Tamez, P.L.; Tushar, D.R.; Rivera-Villareal, R. (2004) Evaluación de la velocidad dehidratación en sistemas puzolanas naturales-portlandita. Revista Ciencia UANL. 8, 190-195. http://eprints.uanl.mx/1606/1/art puzolanas.pdf.

41. Amethyst Galleries, Mineral Gallery. Encyclopedia. http:// www.galleries.com/Cristobalite 